\title{
Effects of acute exposure of chlorpyrifos on the survival, morphology and swimming ability of Odontophrynus carvalhoi tadpoles
}

\author{
Silva, M.B. ${ }^{1}$; Fraga, R.E. ${ }^{1}$; Silva, F.L. ${ }^{1}$; Oliveira, L.A.A. ${ }^{1}$; QueIroz, T.S. ${ }^{1}$; \\ Rocha, M.A. ${ }^{1} \&$ JunCÁ, F.A. ${ }^{2}$ \\ ${ }^{1}$ Universidade Federal da Bahia, Instituto Multidisciplinar em Saúde, BA. Brasil. \\ ${ }^{2}$ Universidade Estadual de Feira de Santana, Departamento de Ciências Biológicas, BA. Brasil
}

Received February 22, 2020; Accept July 17, 2020

\begin{abstract}
This study examines the survival, mortality, morphology and swimming ability of tadpoles exposed to the organophosphate chlorpyrifos (nominal concentrations of 10, 100, 200 e $400 \mu \mathrm{g} \mathrm{L}-1$ ) for $192 \mathrm{~h}$. Odontophrynus carvalhoi tadpoles were used as a biological model. Our findings include decreased survival rates of tadpoles primarily at the highest pesticide concentration (400 $\left.\mu \mathrm{g} \mathrm{L}^{-1}\right)$ and deformities in the caudal muscles, causing spasms and tremors. Tadpoles exposed to chlorpyrifos $\left(10 \mu \mathrm{g} \mathrm{L}^{-1}\right)$ had the lowest swimming speed compared with that of the control group. Tadpoles the other concentrations (100, 200 and 400 $\mu \mathrm{g} \mathrm{L}^{-1}$ ) were not evaluated since none of the survived $192 \mathrm{~h}$ exposure in concentrations above $10 \mu \mathrm{g} \mathrm{L}^{-1}$. These adverse effects indicate that this organophosphate can affect the survival of tadpoles even in small doses, compromising the local population.
\end{abstract} Keywords: Amphibians; Chlorpyrifos, Organophosphorus insecticide, Odontophrynus carvalhoi, Swimming speed, Toxic effects.

\section{INTRODUCTION}

After habitat loss, pollution is considered the most important threat to amphibian populations (Mann et al., 2003). Population declines have been related to proximity to agricultural land and the presence of chemicals (Sparling et al., 2001; Houlahan \& Findlay, 2003; Davidson, 2004; Mann et al., 2009; Lajmanovich et al., 2012), which can cause malformations (Ouellet et al., 1997; Taylor et al., 2005; Mann et al., 2009). Despite the widespread and intensive use of pesticides and the observed decline of amphibian populations, the number of studies that have examined the effects of these pesticides on amphibians is much smaller when compared with other aquatic organisms (Mann et al., 2009). Most research regarding amphibians focuses on acute pesticide lethality (Kamrin, 1997; Cowman \& Manzati, 2000; Greulich \& Pflugmacher, 2003; Sparling \& Fellers, 2009; Agostini et al., 2010; Bernabó et al., 2011, Arcaute et al., 2012). However, evidence of the sublethal effects of pesticides on the growth, development, reproduction and behavior of these organisms already exists (Semlitsch et al., 1995; Bridges, 1997; Kamrin, 1997; Boone \& Bridges, 2003; Chen et al., 2006; Widder \& Bidwell, 2008; Webber et al., 2010; Denoel et al., 2012; Denoel et al., 2013; Yu et al., 2013; Moreira et al., 2019; Pinelli et al., 2019; Nataraj \& Krishnamurthy, 2020; Rutkoski et al., 2020; Silva et al., 2020a; Silva et al., 2020b), emphasizing the requirement for further research, particularly in light of the global decline in amphibian populations (Bruhl et al., 2011).

Recent studies have examined changes in the activity levels and swimming performance in amphibian larvae subjected to pesticides, concluding that morphological endpoints are a valuable indicator of sublethal effects (Bridges, 1997; Chen et al., 2006; Egea-Serrano et al., 2011; Denoel et al., 2012; Janssens \& Stocks, 2012; Denoel et al., 2013, Moreira et al., 2019). Changes in the swimming ability of tadpoles (reductions in distance traveled and in speed) can lead to death or can indirectly alter important life history functions (e.g., growth and development), causing a reduction in foraging and/ or increased vulnerability to predators (Relyea, 2005; Silva,

*Corresponding author: Márcio Borba da Silva; e-mail: biolmarcioborba@gmail.com 
2014; Rutkoski et al., 2020). These variables can negatively affect individual survival and the success of this population.

Organophosphate pesticides are widely used in agriculture, forming the largest group of chemicals used to control pests of invertebrates, vertebrates and, to a lesser extent, plants (Sparling \& Fellers, 2007). Chlorpyrifos is an organophosphate insecticide commonly used on crops, including cotton, potato, coffee, and corn, among others. This organophosphate is highly toxic to aquatic organisms because chlorpyrifos permanently inhibits acetylcholinesterase (AChE), resulting in the accumulation of acetylcholine and the overstimulation of nerve endings that are active in muscle, glandular, ganglion and central nervous system (CNS) cells, thereby causing the loss of respiratory control and, consequently, death by asphyxiation (Colombo et al., 2005; Nobonita \& Suschismita, 2013).

Based on studies that have evaluated the toxic effect of chlorpyrifos on tadpoles of different anuran species (Sparling \& Fellers, 2009; Bernabó et al., 2011; Arcaute et al., 2012), chlorpyrifos toxicity in amphibians was found to be speciesspecific. Only Rana dalmatina tadpoles did not have their mortality rates, growth and time to reach metamorphosis affected by chlorpyrifos (Bernabó et al., 2011), although morphological changes in the tail and gills were observed. These controversial results confirm the requirement for additional studies regarding the effects of chlorpyrifos on tadpoles of other species. Therefore, the objective of this study was to determine the effects of exposure to levels of chlorpyrifos on Odontophrynus carvalhoi (Anura: Odontophrynidae) tadpole survival, morphology and swimming speed because the areas where this species occurs are subject to constant exposure to this product through intense agricultural activity in the region and because the effects of organophosphates on the tadpoles of this species that occurring in northern South America remain unknown.

\section{MATERIALS AND METHODS}

\section{Test organisms}

O. carvalhoi tadpoles were obtained from the hatching of clutches collected from amplexing couples in a protected area in the municipality of Mucugê, Bahia State, Brazil. $O$. carvalhoi couples are found near the banks of streams, and tadpoles live in permanent or temporary streams. This species has restricted distribution in Brazil, inhabiting environments approximately $500 \mathrm{~m}$ above sea level and geographically distributed between the Serra do Espinhaço mountain range (in the west) and the Atlantic Ocean (in the east), from the valley of the Jequitinhonha River in Minas Gerais (in the south) to Paraíba (in the north) (Caramaschi \& Napoli, 2012).

Before the experiments, the tadpoles were acclimated in aquaria (35 L), according to Silva et al. (2020b), which each contained $30 \mathrm{~L}$ of well-aerated water at a temperature of 20 to $25^{\circ} \mathrm{C}$ and with a $12 \mathrm{~h}-12 \mathrm{~h}$ light-dark photoperiod for 30 days. The tadpoles were raised at a density of 2 individuals/L of water. The water was changed every three days, and the tadpoles were fed daily (two pellets per tadpole) with a standard fish food diet (Neon MEP 200 complex $^{\circledR}$, Alcon, Camboriu, Brazil). Pre-metamorphic larvae at Gosner stages 27-31 (Gosner, 1960) were used in bioassays.

\section{Experimental design}

Four treatments were performed with different nominal concentrations of the insecticide chlorpyrifos (Klorpan ${ }^{\circledR}$ 480 EC; 48.98\% purity, O,O-diethyl O-3,5,6-trichloro-2pyridyl phosphorothioate) and dechlorinated water: 10.0 $\mu \mathrm{g}(\mathrm{C} 10), 100.0 \mu \mathrm{g}$ (C100), $200.0 \mu \mathrm{g}(\mathrm{C} 200)$ and $400.0 \mu \mathrm{g}$ (C400) of chlorpyrifos/L of water $\left(\mu \mathrm{g} \mathrm{L}^{-1}\right)$. The insecticide concentrations to be used were defined based on records from aquatic environments in Brazil, especially from localities with intense agricultural activities (Da Silva, 2006) (for more information see in Silva et al., 2020b). These solutions were prepared immediately before each experiment. Chlorpyrifos has a relatively short half-life in the aquatic ecosystem, ranging from 3.5 to 20 days (Kamrin, 1997); therefore, the test solutions were replaced every two days to maintain the experimental concentrations. The water used was well-oxygenated (dissolved oxygen concentration ( $\mathrm{DO}=8.0 \mathrm{mg} \mathrm{L}^{-1}$ of water), with a neutral $\mathrm{pH}(\mathrm{pH}$ 7.0-7.8). These experiments lasted 10 days. For comparison, control groups $(\mathrm{CN})$ containing only dechlorinated water were used. In total, 15 tadpoles were used per treatment and per control group. The tadpoles were individually placed in $800 \mathrm{~mL}$ capacity polypropylene bottles.

\section{Survival}

The survival of the treatment and control group tadpoles was assessed after 24, 48, 96 and $192 \mathrm{~h}$ of exposure to the insecticide. Animals exhibiting movements after being touched with a pipette were considered alive.

\section{Morphological abnormalities, morphometry and swimming ability}

Tadpole morphology was analyzed to detect morphological abnormalities caused by exposure to chlorpyrifos. The types of morphological abnormalities investigated followed the categories analyzed by Agostini et al., (2010).

The tadpoles exposed to chlorpyrifos for $192 \mathrm{~h}$ in the C10 treatment were evaluated for the effect of chlorpyrifos on morphology. Tadpoles the other concentrations (100, 200 and $400 \mu \mathrm{g} \mathrm{L}^{-1}$ ) were not evaluated since none of the survived $192 \mathrm{~h}$ exposure in concentrations above $10 \mu \mathrm{g} \mathrm{L}^{-1}$. The following ten morphological variables were measured in tadpoles of the $\mathrm{CN}(\mathrm{n}=14)$ and $\mathrm{C} 10(\mathrm{n}=13)$ groups: the distance between eyes (ED), diameter of the nostrils (N), body length (BL), height of the tail musculature (HTM), maximum tail height (TH), height at the middle region of the tail (HMT), width of the tail musculature (WTM), height of the dorsal 
fin (HDF), height of the ventral fin (HVF) and width of the oral disc (WD), following the recommendations of other authors (Buskirk \& Mccollum, 2000; Teplitsky et al., 2003; Mercês \& Juncá, 2010), using a Leica MZ6 stereomicroscope (Leica Microsystems, Inc., Wetzlar, Germany) coupled with a micrometric eyepiece.

Tadpole swimming ability was assessed by measuring the swimming speed following the method proposed by Bridges (1997). The tadpoles exposed to chlorpyrifos for $192 \mathrm{~h}$ in the $\mathrm{C} 10(\mathrm{n}=9)$ and $\mathrm{CN}(\mathrm{n}=14)$ treatments were tested to determine whether chlorpyrifos treatment affected tadpole swimming speed. Tadpoles the other concentrations $(100,200$ and 400 $\mu \mathrm{g} \mathrm{L}^{-1}$ ) were not evaluated since none of the survived $192 \mathrm{~h}$ exposure in concentrations above $10 \mu \mathrm{g} \mathrm{L}^{-1}$. The tadpoles were individually placed in polypropylene lanes $(1.6 \mathrm{~cm}$ wide $\times 60$ $\mathrm{cm}$ long $\times 0.6 \mathrm{~cm}$ deep) containing water. After an acclimation period of 10 minutes, each tadpole was stimulated at the base of the tail with a pipette to trigger swimming. The time of the swim (s) and the distance traveled $(\mathrm{cm})$ were determined using a stopwatch and graduated ruler, and this procedure was performed only once per tadpole. Next, the speed of each tadpole was determined.

\section{Statistical Analysis}

Principal component analysis (PCA) was used to graphically assess whether the chlorpyrifos treatments influenced the morphology of tadpoles, with a covariance matrix constructed using the log-transformed morphometric variables. PAST version $2.17 \mathrm{c}$ software (http://folk.uio.no/ ohammer/past/) (Hammer et al., 2001) was used. Those variables with loadings above 0.4 were used to define which morphometric variables better explained the ordination. An unpaired t-test with Welch's correction was used to investigate a possible difference among the averages of relevant variables.

Analysis of variance (ANOVA) was used to determine how the chlorpyrifos treatments affected tadpole survival. Bonferroni's multiple comparison test was used to examine the significant primary effects. All tests were performed using GraphPad Prism 5.00 software (GraphPad Software Inc., San Diego, CA, USA) at a significance level of 0.05 , which was adopted for all tests. Normality was confirmed by the modified Shapiro-Wilks test, and homoscedasticity was confirmed by Bartlett's test. When necessary, the data were log-transformed (continuous data).

Student's t-test was performed to test for significant differences in the swimming speed between tadpoles exposed to chlorpyrifos (C10) for $192 \mathrm{~h}$ and the control group.

\section{RESULTS}

\section{Survival}

The survival of tadpoles exposed to chlorpyrifos solutions differed significantly among the experimental concentrations
$\left(\mathrm{F}_{4,19}=6.084, \mathrm{P}=0.0065\right)$ and exposure times $\left(\mathrm{F}_{3,19}=9.287\right.$, $\mathrm{P}=0.0019)$ (Fig. 1). The $400 \mu \mathrm{g} \mathrm{L}^{-1}$ of chlorpyrifos concentration exhibited the lowest number of survivors compared with the numbers of survivors for the other concentrations. These differences were statistically significant for combinations involving $400 \mu \mathrm{g} \mathrm{L}^{-1}$ of chlorpyrifos and control groups (48 and $96 \mathrm{~h}$ after exposure) and for $10 \mu \mathrm{g} \mathrm{L}^{-1}$ of chlorpyrifos (for $96 \mathrm{~h}$ after exposure $)(\mathrm{P}<0.05)$.

\section{Morphological abnormalities, morphometry and swimming ability}

Morphological changes occurred after $24 \mathrm{~h}$ of chlorpyrifos exposure and were always related to the axis of the tail. Lateral flexion of the tail, which caused a contorted posture, was observed (Fig. 2). These changes were more common after 48 $\mathrm{h}$ of chlorpyrifos exposure. In general, the tadpoles in all tested concentrations (C10, 100, 200 and $400 \mu \mathrm{g} \mathrm{L}^{-1}$ of chlorpyrifos) exhibited abnormalities after $192 \mathrm{~h}$ of chlorpyrifos exposure $(29,26,15$ and $22 \%$ of surviving tadpole, respectively).

The dispersion of values between the axes of principal components 1 and 2 ( $\mathrm{PC} 1$ compared with $\mathrm{PC} 2$ ) indicated morphological differences between the tadpoles exposed to chlorpyrifos for $192 \mathrm{~h} \mathrm{(C10)}$ and the control group (Fig. 3). $\mathrm{PC} 1$ and $\mathrm{PC} 2$ explained $78.92 \%$ of the total data variability. The morphometric variables with the largest contributions (loadings above $40 \%$ ) were the maximum tail height (0.4559) in PC1 and the ventral fin height (0.4344) and the height at the middle region of the tail $(-0.7838)$ in PC2. The tadpoles exposed to chlorpyrifos exhibited the shortest ventral fin heights $(\mathrm{t}=3.907, \mathrm{P}=0.0007 \mathrm{df}=23)$ and the tallest heights at the middle region of the tail $(\mathrm{t}=2.235, \mathrm{P}=0.0302, \mathrm{df}=21)$ compared with those heights of the control group.

The exposed tadpoles were significantly slower when compared with the speed of the control group $(\mathrm{t}=6.399$, $\mathrm{P}<0.0001$, df=16) (Fig. 4.). After $192 \mathrm{~h}$ of exposure to 10 $\mu \mathrm{g} \mathrm{L}^{-1}$ of chlorpyrifos, some observed tadpoles were unable to move, lying sideways, or with the dorsal side down and trembling ( $38.5 \%$ of the total).

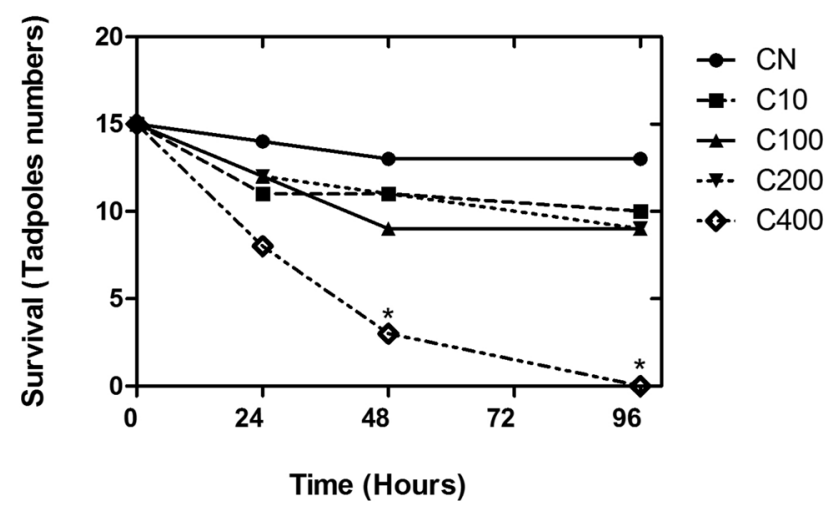

Figure 1: Survival of $O$. carvalhoi tadpoles exposed to different chlorpyrifos concentrations. Asterisks indicate significant differences compared with the control group $(\mathrm{CN})(\mathrm{P}<0.05)$. 

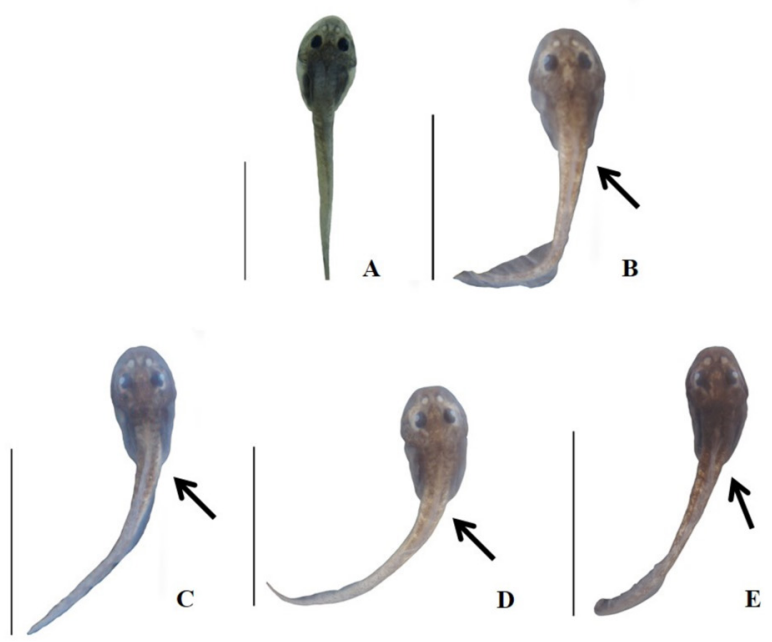

Figure 2: Morphological changes in O. carvalhoi tadpoles exposed to chlorpyrifos. Dorsal view of the curved tails (arrow) after $96 \mathrm{~h}$ of exposure in the control group (A) and at chlorpyrifos concentrations of $10 \mu \mathrm{g} \mathrm{L}^{-1}$ (B), $100 \mu \mathrm{g} \mathrm{L}^{-1}$ (C), $200 \mu \mathrm{g} \mathrm{L}^{-1}$ (D) and $400 \mu \mathrm{g} \mathrm{L}^{-1}$ (E) (scale $=10 \mathrm{~mm}$ ).

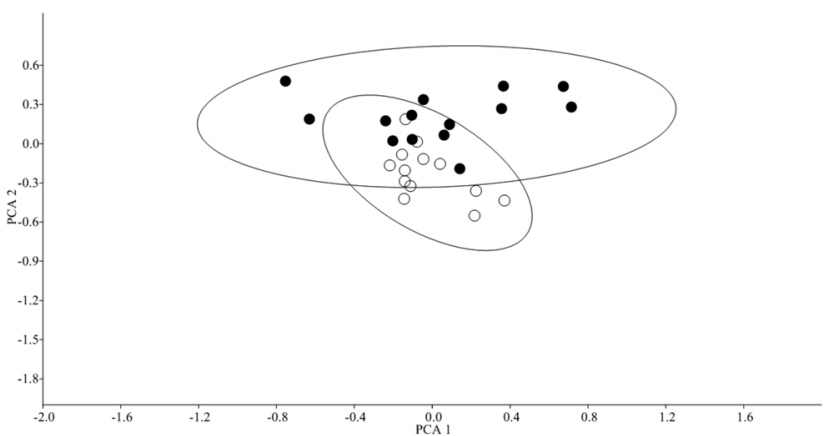

Figure 3: Clusters formed from principal component analysis (PCA) using 10 morphological measurements of $O$. carvalhoi tadpoles exposed to chlorpyrifos $\left(10 \mu \mathrm{g} \mathrm{L}^{-1}\right)$ for $192 \mathrm{~h}$ (black circles) and of the control group (open circles).

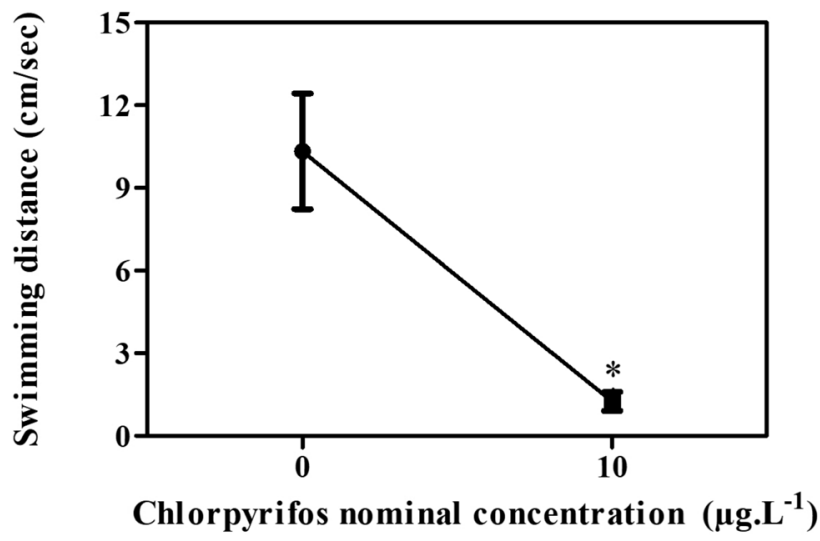

Figure 4: Swimming speed of $O$. carvalhoi tadpoles exposed to chlorpyrifos $\left(10 \mu \mathrm{g} \mathrm{L}^{-1}\right)$ for $192 \mathrm{~h}$. The vertical bars represent the mean \pm standard error.

*Asterisk indicates a significant difference compared with the control group $(\mathrm{CN})(\mathrm{P}<0.05)$.

\section{DISCUSSION}

The present study demonstrated that the insecticide chlorpyrifos, even at low concentrations and beginning at 24 $\mathrm{h}$ of exposure, might decrease the survival of $O$. carvalhoi tadpoles, which is consistent with results found for other tadpole species (Barron \& Woodburn, 1995; Widder \& Bidwell, 2006; Sparling \& Fellers, 2007, 2009; Rutkoski et al., 2020).

Although mortality is the most extreme result of toxicity, sublethal effects may occur at much smaller concentrations (Sparling \& Fellers, 2009; Widder \& Bidwell, 2006), and behavioral and morphological changes are sensitive indicators of the effects of toxic agents.

The behavioral and morphological abnormalities observed in the present study are typical signs of organophosphate poisoning (Richards \& Kendall, 2002, 2003; Colombo et al., 2005; Widder \& Bidwell, 2008; Bernabó et al., 2011; Arcaute et al., 2012; Nobonita \& Suschismita, 2013; Rutkoski et al., 2020). Abnormalities related to the morphology of the tadpole tail and fins could be noticed after $24 \mathrm{~h}$ of chlorpyrifos exposure, as evidenced by the PCA results.

In general, different species of tadpoles that have been exposed to pesticides, particularly chlorpyrifos, have often displayed lateral bending of the tail, twisted posture and muscle disorders, for example, R. dalmatina (Bonfanti et al., 2004; Bernabó et al., 2011), Xenopus laevis (Richards \& Kendall, 2002), Rhinella fernandezae (Greulich \& Pflugmacher, 2003) and Physalaemus gracilis (Rutkoski et al., 2020). This change in the tail musculature could be the consequence of the cholinergic phase promoted by $\mathrm{AChE}$ inhibition, which would cause repetitive firing (continuous contractions) of muscle fibers, injuring the tissue and resulting in muscle disorganization, as reported by some authors (Bonfanti et al., 2004; Colombo et al., 2005; Rutkoski et al., 2020), and hence twisting of the tail.

Physical abnormalities induced by agrochemicals are common in agricultural areas (Mann et al., 2009; Lajmanovich et al., 2012) and may lead to the impairment of tadpole mobility (Richards \& Kendall, 2002, 2003; Widder \& Bidwell, 2008; Rutkoski et al., 2020). Changes in the tail may directly affect swimming performance, promoting erratic swimming and rendering the tadpole unable to balance during swimming phases, as was observed in $O$. carvalhoi, whose swimming speeds were negatively affected by the tested chlorpyrifos concentration. These behavioral abnormalities were also detected in the fish species Danio rerio and Poecilia reticulata (Nobonita \& Suschismita, 2013), as well as in other tadpole species, including Acris crepitans, Hyla chrysoscelis, Gastrophryne olivacea, R. sphenocephala (Widder \& Bidwell, 2008), X. laevis (Richards \& Kendall 2002; Bonfanti et al., 2004), Ceratophrys ornata (Salgado Costa et al., 2018) and Physalaemus gracilis (Rutkoski et al., 2020), at different chlorpyrifos concentrations.

In the present study, chlorpyrifos was shown to decrease $O$. carvalhoi tadpole survival and have caused other relevant 
effects (changes in the tail, making tadpoles slower and, therefore, perhaps more susceptible to predation and/or less efficient at foraging). These effects can affect juvenile recruitment, resulting in changes in the local population structure of the species. Therefore, chlorpyrifos may have a negative effect on tadpoles that inhabit agroecosystems.

\section{ACKNOWLEDGMENTS}

We thank the Brazilian Ministry of the Environment for the permit to conduct the study (ICMBio permit no. 27305-1) and the Ethics Committee on Animal Use of the University (CEUA-UEFS protocol no. 02/2012). This study was funded by the Brazilian National Council for Scientific and Technological Development - (Conselho Nacional de Desenvolvimento Científico e Tecnológico - CNPq): MCT/CNPq no. 59/2009; Long Term Ecological Research Program (Programa de Pesquisas Ecológicas de Longa Duração - PELD); Chapada Diamantina and the Research Support Foundation of the State of São Paulo (Fundação de Amparo à Pesquisa do Estado de São Paulo- FAPESP): SISBIOTA Project: Tadpoles of anurans from the Atlantic Forest, the Amazon, the Pantanal, Cerrado and Transition Zones: Morphological Characterization, Spatial Distribution and Patterns of Diversity (Girinos de Anuros da Mata Atlântica, Amazônia, Pantanal, Cerrado e de Zonas de Transição: Caracterização Morfológica, Distribuição Espacial e Padrões de Diversidade, FAPESP proc. 2010/52321-7 and CNPq proc. 563075/2010-4).

\section{REFERENCES}

AGOSTINI, M.G., NATALE, G.S., RONCO, A.E. 2010. Lethal and sublethal effects of cypermethrin to Hypsiboas pulchellus tadpoles. Ecotoxicology. 19:1545-1550. https://doi.org/10.1007/ s10646-010-0539-3.

ARCAUTE, C.R., COSTA, C.S., DEMETRIO, P.M., NATALE, G.S., RONCO, A.E. 2012. Influence of existing site contamination on sensitivity of Rhinella fernandezae (Anura, Bufonidae) tadpoles to Lorsban ${ }^{\circledR} 48 \mathrm{E}$ formulation of chlorpyrifos. Ecotoxicology. 21:2338-2348. https://doi.org/10.1007/s10646-012-0990-4.

BARRON, M.G. \& WOODBURN, K.B. 1995. Ecotoxicology of chlorpyrifos. Rev. Environ. Contam. Toxicol. 144:1-93.

BERNABÓ, I., SPERONE, E., TRIPEPI, S., BRUNELLI, E. 2011. Toxicity of chlorpyrifos to larval Rana dalmatina: acute and chronic effects on survival, development, growth and gill apparatus Arch. Environ. Contam. Toxicol. 61:704-718. https:// doi.org/10.1007/s00244-011-9655-1.

BONFANTI, P., COLOMBO, A., ORSI, F., NIZZETTO, I., ANDRIOLETTI, M., BACCHETTA, R., MANTECCA, P., FASCIO, U., VAILATI, G., VISMARA, C. 2004. Comparative teratogenicity of chlorpyrifos and malathion on Xenopus laevis development. Aquat. Toxicol. 70:189-200. https://doi.org/ 10.1016/j.aquatox.2004.09.007.

BOONE, M.D. \& BRIDGES, C.M. 2003. Effects of carbaryl on green frog (Rana clamitans) tadpoles: timing of exposure versus multiple exposures. Environ. Toxicol. Chem. 22:2695-2702. https://doi.org/10.1897/02-401.

BRIDGES, C.M. 1997. Tadpole swimming performance and activity affected by acute exposure to sublethal levels of carbaryl.
Environ. Toxicol. Chem. 16:1935-1939. https://doi.org/10.1002/ etc.5620160924.

BRUHL, C.A., PIEPER, S., WEBER, B. 2011. Amphibians at risk? Susceptibility of terrestrial amphibian life stages to pesticides. Environ. Toxicol. Chem. 30:2465-2472. https://doi.org/10.1002/ etc. 650 .

BUSKIRK, J.V. \& MCCOLLUM, S.A. 2000. Influence of tail shape on tadpole swimming performance. J. Exp. Biol. 203:2149-2158.

CARAMASCHI, U.; NAPOLI, M. F. 2012. Taxonomic revision of the Odontophrynus cultripes species group, with description of a new related species (Anura, Cycloramphidae), Zootaxa 3155: $1-20$.

CHEN, T.H., GROSS, J.A., KARASOV, W.H. 2006. Sublethal effects of lead on northern leopard frog (Rana pipiens) tadpoles. Environ. Toxicol. Chem. 25: 1383-1389. https://doi. org/10.1897/05-356R.1.

COLOMBO, A., ORSI, F., BONFANTI, P. 2005. Exposure to the organophosphorus pesticide chlorpyrifos inhibits acetylcholinesterase activity and effects muscular integrity in Xenopus leavis larvae. Chemosphere. 61:1665-1671. DOI: 10.1016/j.chemosphere.2005.04.005.

COWMAN, D.F. \& MAZANTI, L.E. 2000. Ecotoxicology of "new generation" pesticides to amphibians. In SPARLING, D.W., BISHOP, C.A., LINDER, G. eds, Ecotoxicology of Amphibians and Reptiles. SETAC, Pensacola, FL, USA, pp 233-268.

DA SILVA, I.L.A. 2006. Monitoração de pesticidas em ambientes de intensa atividade agrícola na região do norte fluminense. Monograph, Universidade Estadual do Norte Fluminense Darcy Ribeiro, Campos dos Goytacazes, 42p.

DAVIDSON C. 2004. Declining downwind: Amphibian population declines in California and historical pesticide use. Ecol. Appl. 14: 1892-1902. https://doi.org/10.1890/03-5224.

DENOËL, M., LIBON, S., KESTEMONT, P., BRASSEUR, C., FOCANT, J.F., PAUW, E.D. 2013. Effects of a sublethal pesticide exposure on locomotor behavior: A video-tracking analysis in larval amphibians. Chemosphere. 90:945-951. https://doi.org/10.1016/j.chemosphere.2012.06.037.

DENOËL, M., D'HOOGHE, B., FICETOLA, G.F., BRASSEUR, C., DE PAUW, E., THOMÉ, J.P., KESTEMONT, P. 2012. Using sets of behavioral biomarkers to assess short-term effects of pesticide: a study case with endosulfan on frog tadpoles. Ecotoxicology. 21: 1240-1250. https://doi.org/10.1007/s10646012-0878-3.

EGEA-SERRANO, A., TEJEDO, M., TORRALVA, M. 2011. Behavioral responses of the Iberian waterfrog, Pelophylax perezi (Seoane, 1885), to three nitrogenous compounds in laboratory conditions. Ecotoxicology. 20:1246-1257. https://doi. org/10.1007/s10646-011-0673-6.

GOSNER, K.L. 1960. A simplified table for staging anuran embryos and larvae with notes on identification. Herpetologica. 16:183190.

GREULICH, K. \& PFLUGMACHER, S. 2003. Differences in susceptibility of various life stages on amphibians to pesticide exposure. Aquat. Toxicol. 65:329-336. https://doi.org/10.1016/ S0166-445X(03)00153-X.

HAMMER, Ø., HARPER, D.A.T., RYAN, P.D. 2001. PAST: Paleontological statistics software package for education and data analysis. Palaeontol. Electron. 4(1): 9pp. Available in: http://palaeo-electronica.org/2001 1/past/issue1 01. htm.

HOULAHAN, J.E. \& FINDLAY, C.S. 2003. The effects of adjacent land use on wetland amphibian species richness and community composition. Can. J. Fish. Aquat. Sci. 60:1078-1094. https://doi. org/10.1672/0277-5212(2006)26[79:TEOALU]2.0.CO;2.

JANSSENS, L. \& STOKS, R. 2012. How does a pesticide 
pulse increase vulnerability to predation? Combined effects on behavioral antipredator traits and escape swimming. Aquat. Toxicol. 110-111: 91-98. https://doi.org/10.1016/j. aquatox.2011.12.019.

KAMRIN, M. A. 1997. Pesticide Profiles Toxicity, Environmental Impact, and Fate; Lewis Publishers: Boca Raton, FL. 147-152..

LAJMANOVICH, R.C., PELTZER, P.M., ATTADEMO, A.M., CABAGNA-ZENKLUSEN, M.C., JUNGES, C.M. 2012. Los agroquímicos y su impacto en los anfibios: un dilema de difícil solución. Revista. Química. Viva. 3:184-198.

MANN, R.M., BIDWELL, J.R., TYLER, M.J. 2003. Toxicity of herbicide formulations to frogs and the implications for product registration: A case study from Western Australia. Appl. Herpetol. 1:13-22. https://doi.org/10.1163/157075403766451199.

MANN, R.M., HYNE, R.V., CHOUNG, C.B., WILSON, S.P. 2009. Amphibians and agricultural chemicals: Review of the risks in a complex environment. Environ. Pollut. 157:2903-2927. https:// doi.org/10.1016/j.envpol.2009.05.015.

MERCÊS, E.A. \& JUNCÁ, F.A. 2010. Girinos de três espécies de Aplastodiscus Lutz, 1950 (Anura - Hylidae) ocorrentes no estado da Bahia, Brasil. Biota Neotrop. 10 (94): 167-172. https:// doi.org/10.1590/S1676-06032010000400022.

MOREIRA, R.A., FREITAS, J.S., DA SILVA PINTO, T.J., SCHIESARI, L., DAAM, M.A., MONTAGNER, C.C., GOULART, B.V., ESPINDOLA, E.L.G. 2019. Mortality, Spatial Avoidance and Swimming Behavior of Bullfrog Tadpoles (Lithobates catesbeianus) Exposed to the Herbicide Diuron. Water. Air. Soil. Pollut. 230:125. https://doi.org/10.1007/ s11270-019-4168-z.

NATARAJ, M.B.R., KRISHNAMURTHY, S.V.B. 2019. Individual and combined effects of organophosphate and carbamate pesticides on the cricket frog Fejervarya limnocharis. Environ. Geochem. Health. 42:1767-1774. https://doi.org/10.1007/ s10653-019-00418-z.

NOBONITA, D.E.B., \& SUCHISMITA, D.A.S. 2013. Chlorpyrifos Toxicity in Fish: A Review. Curr. World. Environ. 8:77-84. http://dx.doi.org/10.12944/CWE.8.1.17.

OUELLET, M., BONIN, J., RODRIGUE, J., DESGRANGES, J.-L., LAIR, S. 1997. Hindlimb deformities (ectromelia, ectrodactyly) in free-living anurans from agricultural habitats. J. Wildl. Dis. 33: 95-104. https://doi.org/10.7589/0090-3558-33.1.95.

PINELli, C., SANTILlO, A., BACCARI, G.C., FALVO, S., DI FIORE, M.M. 2019. Effects of chemical pollutants on reproductive and developmental processes in Italian amphibians. Mol. Reprod. Dev. 86:1324-1332. https://doi.org/10.1002/ mrd.23165.

RELYEA, R.A. 2005. The lethal impacts of Roundup and predatory stress on six species of North American tadpoles. Arch. Environ. Contam. Toxicol. 48: 351-357. https://doi.org/10.1007/s00244004-0086-0.

RICHARDS, S.M. \& KENDALL, R.J. 2002. Biochemical effects of chlorpyrifos on two developmental stages of Xenopus laevis. Environ. Toxicol. Chem. 21:1826-1835. https://doi.org/10.1002/ etc.5620210910.

RICHARDS, S.M. \& KENDALL, R.J. 2003. Physical effects of chlorpyrifos on two stages of Xenopus laevis. J. Toxicol. Environ. Health. 66: 75-91. https://doi.org/10.1080/15287390306461.

RUTKOSKI, C., MACAGNAN, N., FOLADOR, A., SKOVRONSKI, V., AMARAL, A., LEITEMPERGER, J., DORNELES, M., HARTMANN, P., MÜLLER, C., LORO, V., HARTMANN, M. 2020. Morphological and biochemical traits and mortality in Physalaemus gracilis (Anura: Leptodactylidae) tadpoles exposed to the insecticide chlorpyrifos. Chemosphere. 250. 126162. https://doi.org/10.1016/j.chemosphere.2020.126162.
SALGADO COSTA, C., RONCO, A.E., TRUDEAU, V.L., MARINO, D., NATALE, G.S. 2018. Tadpoles of the horned frog Ceratophrys ornata exhibit high sensitivity to chlorpyrifos for conventional ecotoxicological and novel bioacoustic variables. Environ. Pollut. 235: 938-947. https://doi.org/10.1016/j. envpol.2017.12.096.

SEMLITSCH, R.D., FOGLIA, M., MUELLER, A. 1995. Shortterm exposure to triphenyltin affects the swimming and feeding behaviour of tadpoles. Environ. Toxicol. Chem. 14:1419-1423. https://doi.org/10.1002/etc.5620140819.

SILVA, M.B. 2014. Biomarcadores ecotoxicológicos em girinos como subsídios para monitoramento ambiental. $\mathrm{PhD}$ Thesis. Universidade Federal da Bahia, Salvador, 83p.

SILVA, M.B., FRAGA, R.E., NISHIYAMA, P.B., SILVA, I.S.S., COSTA, N.L.B., QUEIROZ, T.S., ROCHA, M.A., JUNCÁ, F.A. 2020a. Genotoxic effect of the insecticide Chlorpyrifos on the erythrocytes of Odontophrynus carvalhoi tadpoles (Amphibia: Odontophrynidae). Ecotoxicol. Environ. Contam. 15(1): 9-13. https://doi.org/10.5132/eec.2020.01.02.

SILVA, M.B., FRAGA, R.E., NISHIYAMA, P.B., SILVA, I.S.S., COSTA, N.L.B., OLIVEIRA, L.A.A., ROCHA, M.A., Juncá, F.A. 2020b. Leukocyte Profiles in Odontophrynus carvalhoi (Amphibia: Odontophrynidae) Tadpoles Exposed to Organophosphate Chlorpyrifos Pesticides. Water. Air. Soil. Pollut. 231:372. https://doi.org/10.1007/s11270-020-04726-4.

SPARLING, D.W. \& FELLERS, G. 2007. Comparative toxicity of chlorpyrifos, diazinon, malathion and their oxon derivatives to larval Rana boylii. Environ. Pollut. 147:535-539. https://doi. org/10.1016/j.envpol.2006.10.036.

SPARLING, D.W. \& FELLERS, G. 2009. Toxicity of two insecticides to California, USA, Anurans and its relevance to declining amphibian populations. Environ. Toxicol. Chem. 28:1696-1703. https://doi.org/10.1897/08-336.1.

SPARLING, D.W., FELLERS, G., MCCONNELL, L.L. 2001. Pesticides and amphibian population declines in California, USA. Environ. Toxicol. Chem. 20:1591-1595. https://doi. org/10.1002/etc.5620200725.

TAYLOR, B., SKELLY, D., DEMARCHIS, L.K., SLADE, M.D., GALUSHA, D., RABINOWITZ, P.M. 2005. Proximity to pollution sources and risk of amphibian limb malformation. Environ. Health. Perspect. 113:1497-1501. https://doi. org/10.1289/ehp.7585.

TEPLITSKY, C., PLÉNET, S., JOLY, P. 2003. Tadpoles responses to risk of fish introduction. Oecol. 134: 270-277. https://doi. org/10.1007/s00442-002-1106-2.

WEBBER, N.R., BOONE, M.D., DISTEL, C.A. 2010. Effects of aquatic and terrestrial carbaryl exposure on feeding ability, growth, and survival of American toads. Environ. Toxicol. Chem. 29:2323-2327. https://doi.org/10.1002/etc.269.

WIDDER, P.D. \& BIDWELL, J.R. 2006. Cholinesterase activity and behavior in chlorpyrifos-exposed Rana sphenocephala tadpoles. Environ. Toxicol. Chem. 25:2446-2454. https://doi. org/10.1897/05-522R.1.

WIDDER, P.D. \& BIDWELL, J.R. 2008. Tadpole size, cholinesterase activity, and swim speed in four frog species after exposure to sub-lethal concentrations of chlorpyrifos. Aquat. Toxicol. 88:918. https://doi.org/10.1016/j.aquatox.2008.02.008.

YU, S., WAGES, M.R., CAI, Q., MAUL, J.D., COBB, G.P. 2013. Lethal and sublethal effects of three insecticides on two developmental stages of Xenopus laevis and comparison with other amphibians. Environ. Toxicol. Chem. 32(9):2056-2064. https://doi.org/10.1002/etc.2280. 